\title{
PATTERN OF ACQUISITION OF ROTAVIRUS ANTIBODY IN CHILDREN FOLLOWED UP FROM BIRTH TO THE AGE OF THREE YEARS
}

\author{
Alexandre C. Linhares', Valéria R. Melo2, Joana D'Arc P. Mascarenhas', \\ Yvone B. Gabbay ${ }^{1}$ and Ronaldo B. de Freitas'.
}

\begin{abstract}
Nine hundred and forty-eight serum samples from 83 children living in Belem, Brazil, collected'within their first three years of life, were tested for the presence of groupspecific rotavirus-antibody by an enzyme-linked immunosorbent assay (ELISA) blocking-test. Passively transferred maternal antibody lasted about two and half months; subsequentely, low levels of rotavirus antibody started to appear at seven months, reaching a peak at eleven months of age. From one year onwards positivity gradually increased, reaching highest values at 34 months of life. Individual responses were examined in sera from 61 children who were followed up since birth to three years of age: $38(62,3 \%)$ of them developed a long-term immunity following first infection; eleven (18.0\%) children developed a short-term immunity after first infection by rotavirus; seven (11.5\%) had no antibody response within their first three years of life; and 5 (8.2\%) showed positive antibody response from birth to three years old.
\end{abstract}

Key-words: Rotavirus. Antibody. Children.

The worldwide occurrence of rotaviruses as major enteropathogens, has been described by several investigators during the past decade. 27141721 They constitute the single most important cause of diarrhoea requiring admission to hospital and attack rates for severe rotavirus diarrhoea in young children appear to be similar in both developed and developing countries 1 . In the latter regions, where malnutrition represents a common finding, rotavirus diarrhoea certainly accounts for a high fatality-rate among children less than 3 years of age. In Brazil, following the first findings in the North region, many authors have assessed the public health importance of rotavirus diarrhoea throughout the country4 5919 .

Most of the studies carried out to date on rotavirus infection, have dealt with detection of this agent in faeces from diarrhoeic children, and the concomitant evaluation of their immune response.

The precise role of immune response with respect to the pathogenesis of rotavirus infection remains to be fully elucidated. It is believed that local immunity in the gut plays a more important role in protecting against rotavirus diarrhoea than circula-

1. Instituto Evandro Chagas, Fundação Serviços de Saúde Pública - 66050 - Belém, Pará - Brasil.

2. Universidade Federal do Pará, Centro de Ciências Biológicas - 66000 - Belém, Pará - Brasil.

This work was supported by the World Health Organization, Control of Diarrhoeal Diseases Programme and Fundação Serviços de Saúde Pública, Ministério da Saúde. ting antibodies 20 . The latter humoral response, however, may reflect the immunological status of the small intestine, at least in terms of immunoglobulin $\mathrm{A}^{8}$.

Seroepidemiological studies conducted in both temperate $^{6}$ and tropical 1011 countries have clearly demonstrated that most (about $80 \%$ ) of children by the age of three years have antibodies to rotavirus.

Results presented here emerged from a threeyear community-based longitudinal investigation and basically concern the kinetics of acquisition of humoral rotavirus antibodies within the first three years of life.

\section{MATERIALS AND METHODS}

Our community-based investigation was carried out in the periphery of Belem, Para state, North Brazil, involving 83 children who lived under poor hygienic conditions. Between November 1982 and March 1986 they were followed up (since birth), through regular fortnightly visits, with the main purpose of studying both clinical and epidemiological aspects of rotavirus infection. Apart from faecal specimens, which were collected fortnightly (or whenever symptoms of diarrhoea were present), serum samples were taken in the following occasions: at birth, throughout every diarrhoeal episode and, regularly, each six months.

Sera were tested for the presence of groupspecific human rotavirus antibody by an ELISA technique described elsewhere ${ }^{16}$. Briefly, a 100 ul sample of hyperimmune rabbit antihuman rotavirus serum, diluted $1 / 100$ in carbonate-bicarbonate buffer ( $\mathrm{pH} 9.8$ ), was added to each well of a 96-well

Recebido para publicação em 28/10/88. 

followed up from birth to the age of three years. Revista da Sociedade Brasileira de Medicina Tropical 22: 25-29, jan-mar, 1989.

polystyrene microtitration plate (NUNC 239454, Gibco Biocult Ltda., Roskilde, Denmark) and incubate $4^{\circ} \mathrm{C}$ overnight or at $37^{\circ} \mathrm{C}$ for two hours. Plates were then washed six times in phosphate-buffered saline ( $\mathrm{pH} 7.3$ ) which contained Tween 20 (polysorbate) at a final concentration of $0.1 \% \mathrm{v} / \mathrm{v}(\mathrm{PBS} / \mathrm{T})$. Fifty microliters of PBS/T containing $0.01 \mathrm{M}$ EDTA (pH 7.3) (PBS/T/EDTA) were added to the precoated wells; 25 ul of human serum samples (including four negative and two positive controls), diluted 1/20 in PBS/T/EDTA, were added to duplicate wells; and $25 \mathrm{ul}$ of an optimal dilution of a clarified rotaviruspositive human stool in PBS/T/EDTA were added to each well. The plates were incubated at $4^{\circ} \mathrm{C}$ overnight and then washed six times in PBS/T. A $100 \mathrm{ul} \mathrm{sam-}$ ple of a hyperimmune guinea-pig anti-human rotavirus serum, diluted $1 / 10,000$ in $\mathrm{PBS} / \mathrm{T}$ containing bovine serum albumin (BSA) at a final concentration of 1 per cent $\mathrm{v} / \mathrm{v}$ (PBS/T/BSA), was added to all wells. Plates were incubated at $37^{\circ} \mathrm{C}$ for two and one half hours and then washed six times in PBS/T. Then, $100 \mathrm{ul}$ of Kirkegaard and Perry (goat) anti-guinea-pig immunoglobulin $\mathrm{G}$, conjugated with alkaline phosphatase, diluted $1 / 200$ in PBS/T/BSA, were added to all wells. Plates were incubated at $37^{\circ} \mathrm{C}$ for on and a half hours, washed again six times in PBS/T, and 100 ul of p-nitrophenylphosphate substrate (Sigma $104-105,1 \mathrm{mg} / \mathrm{ml}$ ) in 10 per cent $\mathrm{v} / \mathrm{v}$ diethanolamine buffer ( $\mathrm{pH} 9.8$ ) were added. After a 20 -minute incubation at 37 .C, the reaction was stop- ped by adding $50 \mathrm{ul}$ of $3 \mathrm{M}$ sodium hydroxide. Readings of optical density (OD) were performed with a Flow ELISA reader (Multiskan), using a $405 \mathrm{~nm}$ filter. The percentage of blocking value of each specimen was determined as follows: per cent blocking $=$ (mean OD of four negatives - OD of sample) / (mean of OD four negatives - mean of OD of two positives) $x 100$. All samples that yielded a per cent blocking value of greater than 25 were regarded as positive.

\section{RESULTS}

Nine hundred and forty-eight sera from 83 children were tested for the presence of group-specific rotavirus-antibody, with the purpose of determining the pattern of acquisition of immunity within the first three years of age. Figure 1 shows mean values of percentages of blocking of these sera in relation to the age in months and number of children of whom specimens were collected. Cord blood samples yielded relatively high levels of rotavirus antibody (percentage of blocking greater than 50), which gradually declined to negative values at 2-3 months of age. Low levels of rotavirus antibody start to appear at seven months, reaching a peak at eleven months of age. From one year onwards, children had progressively increasing ELISA antibody rates with increasing ages; the highest percentage of rotavirus antibody was reached at 34 months of age.

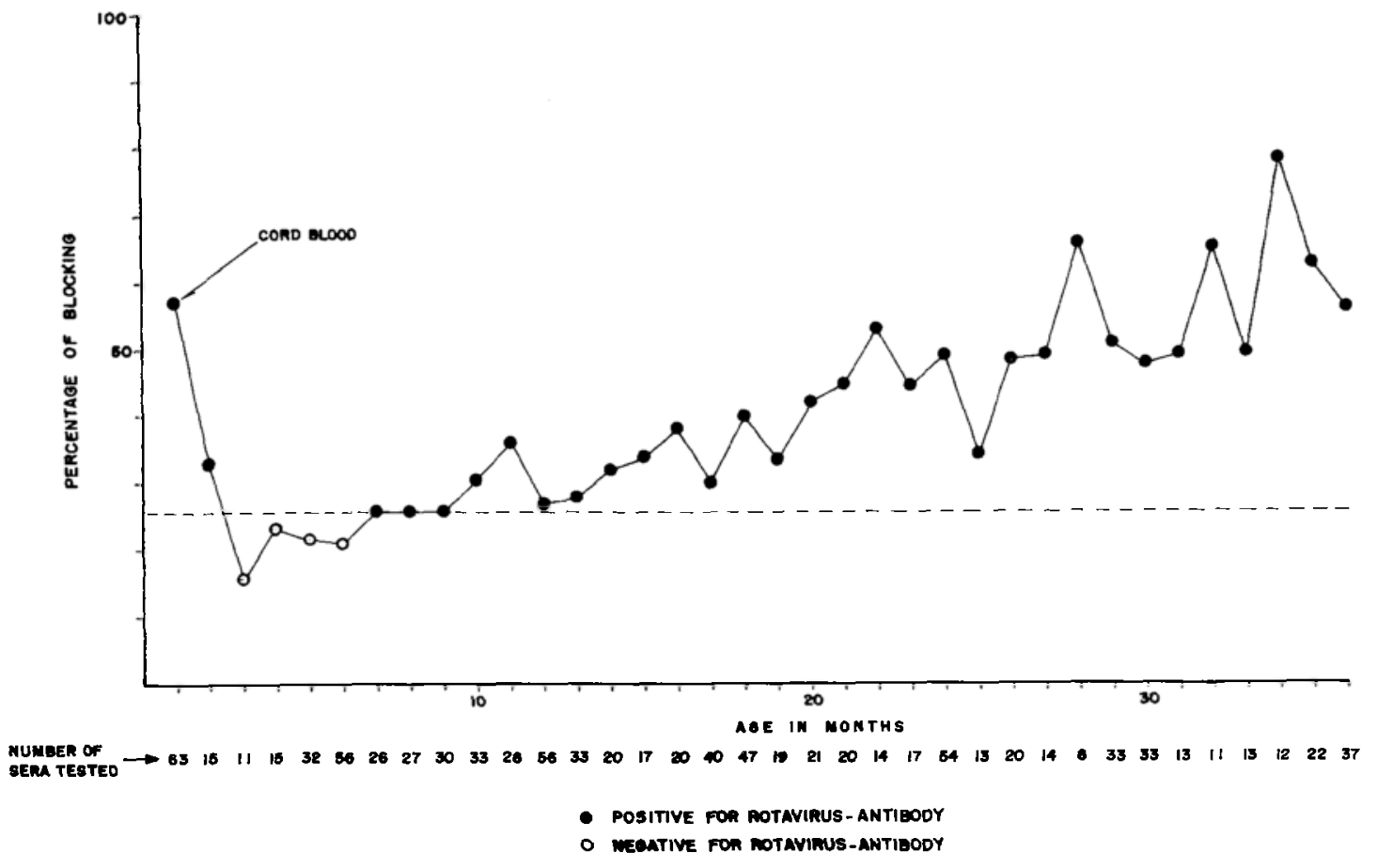

Figure 1 - Rotavirus antibody in 948 sera from 83 children, measured as mean values of percentages of blocking, according to age 
Linhares AC, Melo VR, Mascarenhas JDP, Gabbay YB, Freitas RB. Pattern of acquisition of rotavirus antibody in children followed up from birth to the age of three years. Revista da Sociedade Brasileira de Medicina Tropical 22: 25-29, jan-mar, 1989.

Figure 2 shows the immune response of ten different patterns of immune response to rotavirus infection, as evaluated in 61 children who were followed up from birth to three years of age. Diagrams $A$ and $B$ show the pattern of immune response of 38 $(62.3 \%)$ children who developed a long-term immunity following first infection; figures $2 \mathrm{C}, \mathrm{D}, \mathrm{H}, \mathrm{I}$ and $\mathrm{J}$

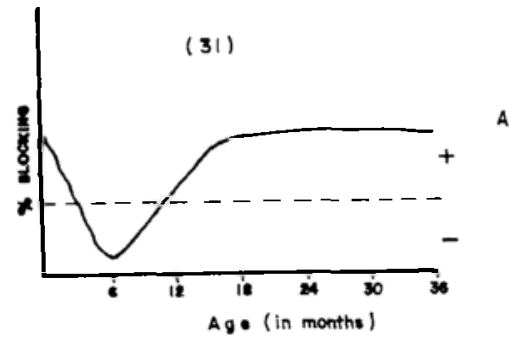

$(7)$
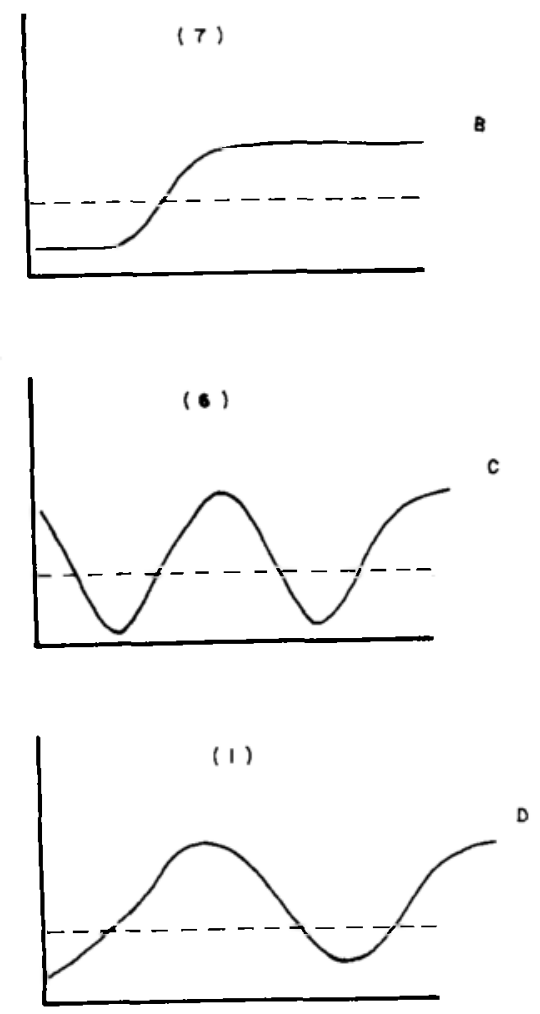

(5)

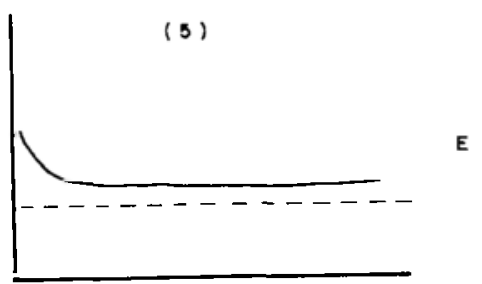

present patterns of short-term immune responses yielded by eleven $(18,0 \%)$ children; seven $(11.5 \%)$ individuals had no antibody response within their first three years of life, as shown in diagrams $2 \mathrm{~F}$ and $\mathrm{G}$; and $5(8.2 \%)$ had rotavirus antibody positivity since birth to three years of life (Figure 2E).
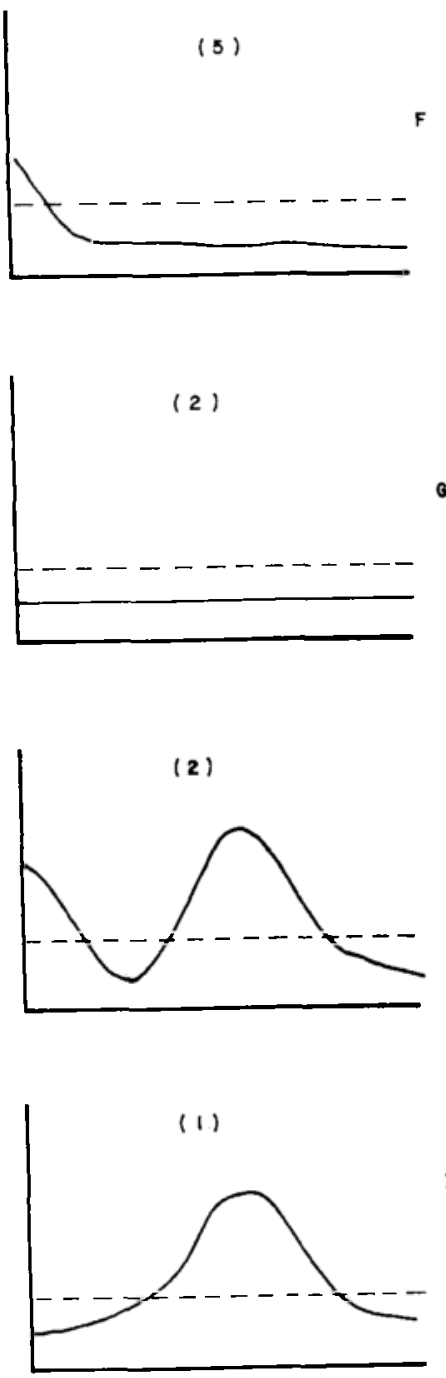

( ) NUMBER OF CHILDREN

Figure 2 - Diagrams concerning different patterns of immune response to rotavirus infection. 
Linhares AC, Melo VR, Mascarenhas JDP, Gabbay YB, Freitas RB. Pattern of acquisition of rotavirus antibody in children followed up from birth to the age of three years. Revista da Sociedade Brasileira de Medicina Tropical 22: 25-29, jan-mar. 1989.

\section{DISCUSSION}

Previous studies conducted in both temperate 3 and tropical 13 regions, have shown that early rotavirus infection (i.e. infections which occur within the first 34 months of life) are more likely to be asymptomatic. The reason for this is not yet well understood. It is possible that circulating antibodies, which may reflect the status of intestinal immunity, can play a role in this context. Our longitudinal investigation has shown that passively transferred maternal antibodies in general disappear after 3 months of age. The children would therefore become susceptible to rotavirus diarrhoea. We also believe that, in the light of our findings, administration of a possible rotavirus vaccine should not be carried out within the first month of life, because of interference which might occur in the presence of high levels of maternal antibody in blood serum.

After six months, children had progressively increasing ELISA antibody rates with increasing age, reaching a peak at eleven months of age. This finding strongly suggests that the rate of rotavirus infection in our region is greatestin children aged 6-24 months. Other authors in both temperate and tropical countries have yielded remarkably similar results with respect to the incidence rate of rotavirus disease among children less than one year of agel.

The interval between the complete decline of passively transferred maternal rotavirus antibody and the emergence of naturally acquired rotavirus is of 2-3 months. This immunological "window" may reflect the absence of rotavirus infection in most of the studied children, from their third to five months of life. It is possible that maternal milk, containing anti-rotavirus secretory IgA (and other non-immune factors), could play a role in protecting them from rotavirus infection 22 . In our region breast feeding is observed in general from birth to six months of age, particularly among children belonging to the low socio-economic level.

The evaluation of individual immune responses among 61 children who were followed up from birth to three years of age yielded ten different patterns, which can be divided into three groups: a) that involving children who apparently developed a long-term immunity; b) those who had a short-term immunity; and c) the children who surprisingly did not show any serological evidence of rotavirus infection.

Immune responses of either short or long duration have already been described with respect to gastroenteritis caused by Norwalk agent ${ }^{18}$. In our investigation, the apparent long-term immunity against rotavirus could perhaps be a result of repeated infections involving different serotypes. Previous studies by us 12 indicate that all four human rotavirus serotypes circulate in our region; serotype 1 is the most prevalent within the first year of life, whereas serotype
2 is mainly detected during the second and third years of life; serotype 4 occurs throughout the first three years of life and serotype 3 is the less prevalent, accounting for a relatively low number of cases of rotavirus infection.

The occurrence of short-term immunity may indicate that following first infection by one rotavirus serotype, a child can further become susceptible to the same serotype. Studies on this particular subject are required in order to determine whether neutralizing antibodies (not detected by our ELISA assay) would also be of limited duration. Another possibility is that our blocking test used to detect group-specific rotavirus antibody is not sufficiently sensitive to demonstrate low levels of serum antibodies.

With regards to the seven children who did not develop antibody response throughout the three-year longitudinal study, we could postulate the following: a) they were immunocompromised, probably by severe malnutrition; b) they in fact had no rotavirus infection during their first three years of life and therefore did not develop serum antibody; and c) their immune response was not detected by our ELISA blocking test, probably they had too low levels of serum antibodies.

Further and broader studies on the immune response to rotavirus infection are necessary, particularly with respect to the serotype-specific immunity. A better understanding of this subject is of importance regarding further strategies of administration of a suitable vaccine.

\section{SUMÁRIO}

Amostras de soro, em número de 948, foram coletadas de 83 crianças, ao longo de seus três primeiros anos de vida, e testadas quanto à presença de anticorpos grupo-especificos para rotavirus por um teste de bloqueio, utilizando-se o ensaio imunoenzimático (ELISA). Observou-se que anticorpos transferidos passivamente pela mãe persistiram por cerca de dois e meio meses; subseqüentemente, baixos niveis de anticorpos para rotavirus começaram a aparecer aos sete meses de idade, atingindo um pico por volta dos onze. A partir de um ano a positividade aumentou gradualmente, alcançando os mais altos valores aos 34 meses de vida. Respostas imunes individuais foram avaliadas em 61 crianças acompanhadas desde o seu nascimento até os três anos de idade, obtendo-se os seguintes resultados: 38 $(62,3 \%)$ delas desenvolveram imunidade de longa duraçāo, após a primo-infecção; $11(18,0 \%)$ indivíduos apresentaram anticorpos especificos que se mantiveram por um intervalo de tempo relativamente curto; $07(11,5 \%)$ não exibiram qualquer resposta imune ao agente em questão, ao longo dos seus três primeiros anos de vida; e $05(8,2 \%)$ mostraram-se 
Linhares AC, Melo VR, Mascarenhas JDP, Gabbay YB, Freitas RB. Pattern of acquisition of rotavirus antibody in children followed up from birth to the age of three years. Revista da Sociedade Brasileira de Medicina Tropical 22: 25-29, jan-mar, 1989.

positivos quanto à presença de anticorpos para rotavírus, desde o nascimento até os três anos de idade.

Palavras-chaves: Rotavirus. Anticorpos. Crianças.

\section{ACKNOWLEDGEMENTS}

We thank Mrs. Margarete Figueiredo Garcia for typing the manuscript.

\section{REFERENCES}

1. Bishop RF. Epidemiology of diarrhoeal disease caused by rotavirus. In: Holmgreen J, Lindberg A, Mollby R (ed.). Development of vaccines and drugs against diarrhoea p. 158-170. 11 th Nobel Conference, Stockholm, Sweden, 1985.

2. Bishop RF, Barnes GL, Cipriani E, Lund JS. Clinical immunity after neonatal rotavirus infection. A prospective longitudinal study in young childrens. The New England Journal of Medicine 309: 72-76, 1983.

3. Cameron DJ, Bishop RF, Veenstra AA, Barnes GL, Holmes IH, Ruck BJ. Pattern of shedding of two noncultivable viruses in stools of newborn babies. Journal of Medical Virology 2: 7-13, 1978.

4. Candeias JA, Rosenberg CP, Racz ML. Identificaçào por contraimunoeletroforese de ratavirus em casos de diarréia infantil. Revista de Saúde Pública (São Paulo) 12: 99-103, 1978.

5. Coiro JRR, Bendati MMA, Almeida Neto AJ, Heuser MCF, Vasconcellos VL. Rotavirus infection in Brazilian children with acute enteritis: a seasonal variation study. American Journal of Tropical Medicine Hygiene 32: 1186-1188, 1983.

6. Elias MM. Distribution and titres of rotavirus antibodies in different age groups. Journal of Hygiene 79: 365-372, 1977.

7. Gurwith M, Wenman W, Hinde D, Feltham S, Greenberg H. A prospective study of rotavirus infection in infants and young children. Journal of Infectious Diseases 144: 218-224, 1981.

8. Hjelt K, Grauballe PC, Paerregaard A, Nielsen OेH, Krasilnikoff PA. Protective effect of preexisting rotavirusspecific immunoglobulin A against naturally acquired rotavirus infection in children. Journal of Medical Virology 21: 39-47, 1987.

9. Houly CA, Uchoa MM, Zaidan AM, Gomes-Neto A, de Oliveira FM, Athayde MA, Almeida MFL, Pereira HG. Electrophoretic study of the genome of human rotavirus from Maceio, Brazil. Brazilian Journal of Medical and Biological Research 19: 33-37, 1986.

10. Ishak R, Linhares AC, Gabbay Y, Ishak MOG, Cardoso DDP. Soroepidemiologia de rotavirus em uma população infantil, Goiânia, Goiás, Brasil. Revista do Instituto de Medicina Tropical de São Paulo 26: 280-284, 1984.

11. Linhares AC, Ferreira FS, Maues BC, Benchimol JA, Gabbay YB. Prevalência de anticorpos para rotavirus em crianças diarréicas de Belém, Brasil. Revista da Fundaçà SESP 28: 95-105, 1983.

12. Linhares AC, Gabbay YB, Freitas RB, Mascarenhas
JDP, Flewett TH, Beards GM. Epidemiology of rotavirus subgroups and serotypes in Belem, Brazil: a threeyear study. Annales de l'Institut Pasteur/ Virologie 139: 89-99, 1988.

13. Linhares AC, Gabbay YB, Freitas RB, Mascarenhas JDP, Salbe E. Longitudinal study of rotavirus infections among children living in Belem, Brazil. Epidemiology and Infection. In press.

14. Linhares AC, Monçāo HC, Gabbay YB, de Araujo VL, Serruya AC, Loureiro EC. Acute diarrhoea associated with rotavirus among children living in Belem, Brazil. Transactions of the Royal Society of Tropical Medicine and Hygiene 77: 384-390, 1983.

15. Linhares AC, Pinheiro FP, Schmetz C, Muller G, Peters D. Douvirus (rotavirus) em Belém do Pará, Brasil, Nota Previa. Revista do Instituto de Medicina Tropical de São Paulo 19: 278-279, 1977

16. Linhares AC, Salbé EV, Gabbay YB, Rees N. Prevalence of rotavirus antibody among isolated South American Indian communities. American Journal of Epidemiology 123: 699-709, 1986.

17. Mata L, Simhon A, Urrutia JJ, Kronmal RA, Fernández R, Garcia B. Epidemiology of rotaviruses in a cohort of 45 Guatamalan Mayan Indian children observed from birth to the age of three years. Journal of Infectious Diseases 148: 452-461, 1983.

18. Parrino TA, Schreiber DS, Trier JS, Kapikian AZ, Blacklow N. Clinical immunity in acute gastroenteritis caused by Norwalk agent. The New England Journal of Medicine 297: 86-89, 1977.

19. Pereira HG, Azeredo RS, Leite JP, Candeias JA, Racz ML, Linhares AC, Gabbay YB, Trabulsi JR. Electrophoretic study of the genome of human rotaviruses from Rio de Janeiro, São Paulo and Para, Brazil, Journal of Hygiene 90: 117-125, 1983.

20. Riepenhoff-Talty M, Bogger-Goren S, Li P, Carmody PJ, Barret HJ, Ogra PL. Development of serum and intestinal antibody response to rotavirus after naturally acquired rotavirus infection in man. Journal of Medical Virology 8: 215-222, 1981.

21. Rowland MG, Goh SG, Williams K, Campbell AD, Beards GM, Sanders RC, Flewett TH. Epidemiological aspects of rotavirus infection in young $\mathrm{G}$ ambian children. Annals of Tropical Paediatrics 5: 23-28, 1985.

22. Totterdell BM, Nicholson KG, MacLeod J, Chrystie IL, Banatvala JE. Neonatal rotavirus infection: role of lacteal neutralising alpha anti-trypsin and nonimmunoglobulin antiviral activity in protection. Journal of Medical Virology 10: 37-44, 1982. 